\title{
16 Storytelling Nature-spirituality: An Autoethnographic Journey of Rediscovery
}

\section{Introduction}

What is the role of storytelling Nature-spirituality in sustainability of public land? Too often our spirituality detaches itself from the aliveness of Nature, how even the rocks, trees, and seedlings are spiritual. Too often I forget I am not in Nature, I am Nature. Nature is separate from us, and just de-spirited, becomes calculable material resource, a thing that is lifeless. It is not just organizations that abuse Nature. This is an autoethnographic journey of rediscovering my spiritual self, my living story (Bøje, 2005, 2012). It is easy to let ego take charge, and to just carry on. In this case, there are mobs of neighbors doing illegal dumping, setting fire to trees and shrubs, just to have a good ole time. As someone who loves nature, it's hard to offer love and forgiveness. This combination of de-spirited Nature by most government organizations and some (but not a majority of) neighbors who treat public land as a free dump site has led to the tragedy of the commons. The aliveness of Nature has been marginalized, its spirituality not treated seriously. How do I reconnect with the spiritual of Nature? My approach is a return to 'Indigenous Ways Of Knowing' (IWOK) that might inspire changes in 'Western Ways Of Knowing' (WWOK). In this way, the trees, rocks, water, the microbes invisible to the naked eye, have their living spiritual Nature. I want to find out if a spiritual approach to public land, its soil, water, vegetation, and ensemble-aliveness can make some kind of difference to mobs. This is a case study, an autoethnography of my spiritual encounters with public land abuse, and learning to hear Mother Nature's voice, her aliveness of spirit, and my ethical answerability to let her take care of her air, water, earth, and fire.

\section{Prologue}

Sometimes I listen but I don't hear. This makes it harder to hear Nature. For example, in 1995, Grace Ann Rosile took me to meet a Jain Monk. He gave me a Jain name, 'Arihant' by the Gurudev Shree Chitrabhanu (1978, 1979a, 1979b, 1980). I asked, "what does it mean?" He replied, and I wrote it in my notebook this way, "You are conqueror of your inner enemies. Meditate on it daily." I did so for ten years, then came back, tired and exhausted, and asked for a new name. He asked what I was doing. I told him, "each morning I meditate on my inner enemies and how to conquer each of them. I have so many enemies, I want a new name.” He 
told me, "Arihant means you have no enemies, everyone is your friend." Why did this mishearing happen? I was programmed with an academic mind, a 'Western Way of Knowing' (WWOK) and was still in the grip of its programming. Each wordthought I grew up into has a thousand vibrant energies of WWOK culture, society, education, politics, media, and capitalism. Daily meditation was helping me to not just listen, but to actually hear a spiritual voice.

I keep learning the difference between my listening and my hearing. August 2020, after a Vision Quest in the Organ Mountains of New Mexico, Mike ThreeBears, (on Zoom due to the pandemic), gave me the name, 'Surrenders to Spirit.' Again, I misheard my name, writing down 'Sacrifices to Spirit' in my notebook. I am getting used to this new answer. To 'who I am?' 'Surrenders to Spirit' is who I am in my own living story, and in my shamanic drumming meditation daily practice sessions. I am only now hearing the name, seeking its meaning.

\section{No Good Deed Goes Unpunished}

I began noticing this year, after Vision Quest 2020, I was accused by local teens and some young adults of being this grumpy old man. All I was doing was picking up trash, trying to keep the ephemeral pond, located on public lands habitable to the aquatic life that was seasonal. I was picking up all the trash, the broken beer bottles, shotgun shells, and plastic water bottles, and even diapers and COVID-19 masks. A nasty mess, somewhat dangerous to even venture to the pond. The teens and some adults, with the pandemic, had escalated. They were burning tires, pallets and junked furniture. I photographed the mess on my morning walks. I wanted to help Mother Nature. You will see, as I unfold and unpack the case, perhaps Mother Nature, can take care of herself. I was shoveling the burn piles of trash. I thought the fires had gone out. But shovel full after shovel full, into the bed of our pickup truck, and sometimes it caught fire, and I'd put it out with shovel full of sand, again and again. What I learned is I had become a meddling enabler and not at all helping the teens do what I had done at their age, have a booze-fest in the wild. I always packed out, but that is how my dad taught me. As you shall see, I was not helping Mother Nature, and that to understand spirituality of Nature, I had to learn my role.

I found myself picking up the litter, hauling the illegally dumped mattresses, tire, and broken furniture to the landfill. I actually made an earthship greenhouse out of the tires, and some compost bins out of a few of the pallets. But, the amount of dumping week after week, was overwhelming. So I put it into the dump site. There were fires set in the pond, and several days each week scores of beer, wine, and liquor bottles, plus lots of plastic soda and water bottles. Burning tires, mattresses, and pallets leaves, a mess of melted glass chards, nails, radial wire, and 
springs. It's a nasty mess and takes days to clean up. I'd shovel it into the pickup bed, and use magnets to gather the nails and screws. Then off to the land fill, and pay the $\$ 4$ fee to be able to shovel it into an ash bin, which would take me several hours.

The pickup I drive caught fire, when I loaded the burn pit, still smoldering and smoking, in the back. Then as I unloaded the ash pit into the dumpster at our ranch, it caught fire. Each time, I shoveled sand and put out the fire, only to have it catch fire again and again. So I ran to our barn, and began carrying buckets of water and throwing them at the flames in the dumpster. I finally managed to carry the fire from the burn pile to the dumpster on our ranch. I became like Mickey Mouse in Fantasia, carrying a pail of water in each hand, putting out the fire. And it kept reigniting. Even a day later it reignited and burned the lids off the dumpster and all the paint. So I stopped picking up teen's trash and went out to just enjoy the desert life.

On President Biden Inauguration Day the errant neighbors began pouring gasoline on the ground and just burning entire trees and shrubs where they stood. I suppose it was less work to rip branches off trees, or just ignite an entire tree, than to actually perform the labor of hauling the discarded material to the pond. I had done the usual storytelling things. I made reports of license plates and photos of the burn events, the illegal dumping, and so on to the Sheriff's Office. I contacted the codes enforcers of city and county government. All to no avail. With the COVID19 pandemic, public agencies were overwhelmed, were working split-shifts, and were understaffed. I did manage to meet up with two codes officers. We wore our masks and toured the dump sites. They told me forensic stories. From the look of the trash, there is an underground business happening. The illegal trash looks like a business that removes junk from backyards and cleans up houses (or apartments) after someone has passed or moved, and everything of real value was sold off. Instead of paying a \$4 landfill fee, and driving the three miles to the local transfer site, they just drive onto public land and dump it for free. I asked if they could catch them.

It's hard. You have to catch them in the act. They post sentries and by the time there's a report, and you head out there, they've scattered. Even when you catch them, they say there's 'no signs' or 'did not know it was public land' or 'everyone does it. What's the big deal?'

I showed the codes officers jettisoned envelopes and receipts with names and addresses. "They just tell you, someone stole their trash, and they had no idea how it got there.” As it turns out, it's all but impossible to catch illegal dumpers. I heard that the Bureau of Land Management (BLM) was installing motion-activated wildlife cameras in an effort to catch illegal dumpers in the act. BLM parcels are nearby, and most neighbors think its all BLM. So, I wrote letters to the editor, thanking BLM for putting the hidden camera on public land. This act of storytelling lowered the 
incidence rate for a month, but once no actual fines for levied and no arrests, the dumping returned with a vengeance. It actually got worse.

I organized several Zoom meetings with neighbors, and invited city and county officials. One official, from a neighboring district showed up. The sheriff's office told me to stop bothering them. It was not just trash, but neighbors (some of them, not many) head to the desert public land to do target practice. They shoot automatic and semi-automatic weapons of every descriptions. It gets noisy during hunting seasons. In and out of hunting season, any weekend, and some weekdays, there is a lot of gun fire. Sparkles (my dog) is very sensitive to gunfire, while Cuddle-bear (my other dog) couldn't care less. I am a Vietnatm War veteran, so I am used to gunfire. Sparkles stops at the sound of gun fire, freezes motionless in her tracks, and waits there till I head for home. When I am out running with the dogs, and the armed citizens assemble, sometimes we mingle. I used to just walk among them, and collect the trash. After a few encounters, some jeering, 'hey here's a diaper, pick it up, old man' I decided it was not a good idea.

My neighbors who had dads who taught them to respect Nature, to pack out, to obey the laws, and so on - said the pond was a lost cause. Since the COVID-19 pandemic, the mob had taken over its territory. There is just nothing to be be done. So I turned to spiritual intervention. Each day I go out too early for the gun slinger, drinking crowd to be awake, and do some shamanic drumming, alternating, one day at the pond, the next day, down in the Alameda Arroyo. So, one day I encounter the burned trees, the ash pit, the usual assemblage of broken bottles and trash, and the next day, I get some peaceful Nature, where there is still some liter but not so much it overwhelms you. A friend told me to do this experiment. Close your eyes, feel the energy around you, and point in the direction of the most energetic area. Odds are, you will be pointing to liter, because people without spiritual mooring, sense a spiritual place, and toss their garbage onto it. Could it be the most spiritual places of public land, have the biggest trash heaps?

\section{How Do I Make Sense of all This?}

What are the antenarrative processes constitutive of these multi-use public land and water narratives? (Bøje, 2012) I put a storyboard together to depict the underlying processes.

Swainson Hawks that nest in this place, all the trillions of biotic microcosm life beneath my feet, constitute life here. The quantum energy filed includes Grandfather and Grandmother Hackberry Trees, and their seeds. I began to eat the pulpy flesh of the seeds, as my dieta (Bøje \& Henderson, 2014; Henderson \& Bøje, 2016). Already a vegan, the fasting preparation was not difficult. Dieta involves ingesting the seed pulp, aligning with the plants vibrations and my inner body vibrations in 

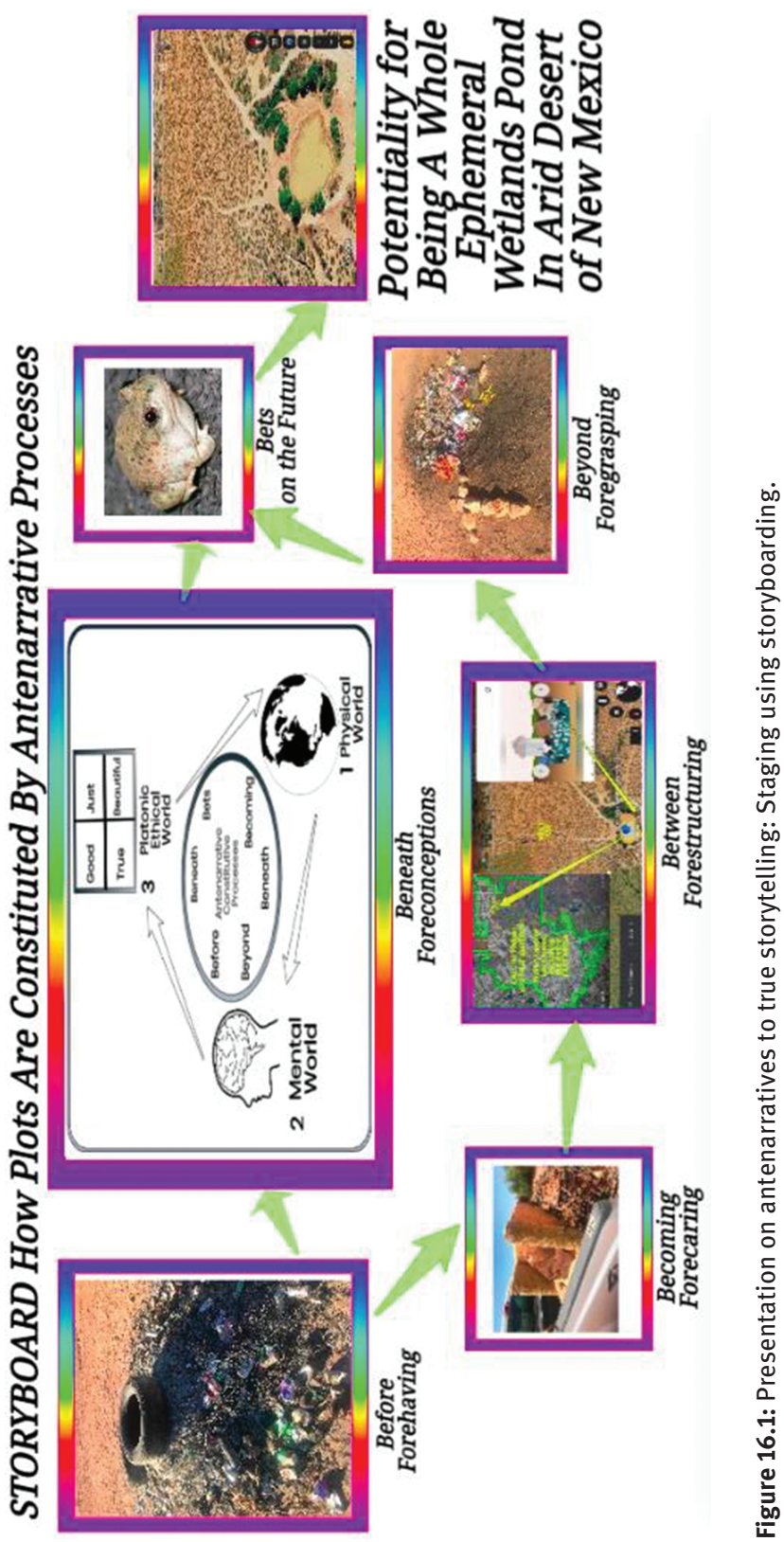
the "indisputable presence” (Gagliano, 2018) of our Beneath (pre-words, pre-language) and our Beyond (fore-grasping intuitive spiritual presence).

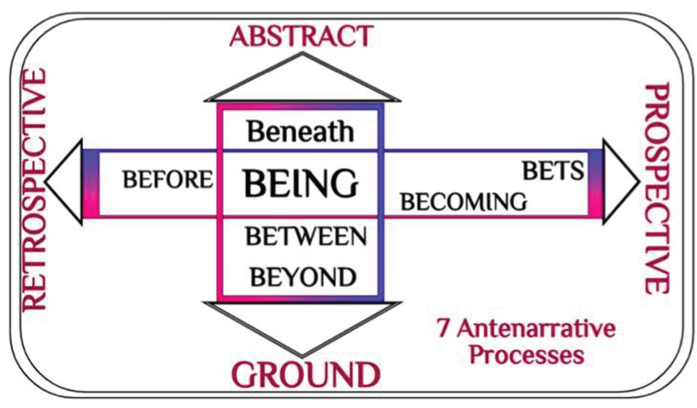

Figure 16.2: Seven antenarrative processes in-context.

I want to stress how important it is that we are all breathing the same air as the grandparent trees, nourished with the same water vapor atmosphere, the vibrations of life, the breathing in and out, during the shamanic drumming, it penetrates me.

At each inhalation, free oxygen breathed out by plants enters into us in all it levity and allows us to convert what we eat into energy. At each exhalation, we let go of carbon dioxide and water, which plants ingeniously combine with a touch of sunlight to make their own food and, once again, more oxygen.

(Gagliano, 2018, p. 15)

Tree and human partake of the same air, water, earth, and fire elements of life. With each breath, in and out, I reflect I am more plant-like, more aware of the community of plants, those ensemble colonies of trillions of living cells in my body, within my own Self, because I am an earthy being. I am in inseparable exchange of carbon, water, and nutrients with plant life. In my dieta, begun in June 2020, my daily meditative shamanic apprenticeship, my humble request to approach Grandfather and Grandmother Hackberry Trees in the Chihuahua Desert, I was engaged in antenarrative relational processes pre-constitutive of the story I now tell. I have begun learning hackberry tree. By August 2020 I was preparing for the Vision Quest, Michael ThreeBears offered to me. My dieta of consuming a few hackberry seed pulps (seed itself much to hard to eat), becomes a seed to plant. During the August Vision Quest, of course many spiritual encounters, the dieta, unfolded. In December 2020, I began planting fallen hackberry seeds, moving them to mulchy areas protected by the grandparent trees. I was growing four that sprouted and still grow in our home nursery. Antenarratively, this is about getting into Being, the Beyond, and the Beneath (the vertical energy work) of working with vibrant mattering energy waveforms. For Vision Quest, I collected a fallen Grandfather Hackberry Tree branch for a Talking Stick to use in the ceremony. This is my dieta relation of my 'I Am' with the Grandfather Hackberry Tree's 'I Am.' 
I started to research the antenarratives, behind the narratives and stories being spun by various city, county, state, and federal agencies. The technical terms (Before, Beneath, Bets, Becoming, Being, Between and Beyond) are from my work on the science of storytelling (Larsen et al., 2020).

BEFORE - In the past burning tires, pallets, plastic bottles, aluminum cans, and mattresses leaves a toxic mess.

BENEATH - To tell this story, you need concepts (foreconceptions) and here I show the relation between concepts of Physical World, Mental Word (what story is in head of people dumping and burning, polluting and breaking laws) and the Mental World of the government, the residents looking as bystanders doing nothing.

BEING - In existentialism, particularly Heidegger, Being-There is an uncovering ways of BEING' in place/space we inhabit here-and-now. "To free oneself for a binding directedness is possible only by being free for what is opened up in an open region" (Heidegger, 2003, section on Ground of Correctness)

BETS ON THE FUTURE - What future do all the characters (government \& business, universities, \& environment organizations, and residents of New Mexico) want. The leases raises money for schools, However, currently the parcel is not leased for anything.

BECOMING - I haul out the burn pit each time it reappears, and haul out the daily litter. Good news, for last five days June 19 to June 23 2020, no more litter or burn pits. It's peaceful place with potential.

BETWEEN - The jurisdictions for governing the uses and care of the land fall in-between the infrastructure of City, County, and Federal - State Land Office. Most residents and many officials assume it is BLM that has jurisdiction. Not True at all.

BEYOND - means intuitive that is beyond the five senses, and here I am working with Shamanic Drumming Circle folks who came up with this idea to storyboard the situation.

More About Being-There. For example, a narrative is "never a presuppositionless apprehending of something presented to us" it's a "fore-given" (Heidegger, 1926, 1962). BEING is not the empirical (that is the ontic). Rather, BEING is something veiled, and we do an uncovering, by going to deeper levels. Being is not just the now, it is the place, the here-and-now of a Situation. Things in the here-now, are either present-at-hand (such as some broken tool that is unusable) or ready-to-hand in a process such as in blacksmithing, a hammer that works, and is accessible, is ready-to-hand.

Another Example: The Trees are already BEING-in-the-World. The trees are present-at-hand. Yet, if the concept of bonfire (BENEATH) changes to, burn trees 'ready-to-hand' in site, in the here-now, then BEING (fore-given) shifts. If trees are natural living systems of Nature, and if those trees have entanglements of many 
other microscopic species (fungi, microorganisms, bacteria), and many other species (birds, toads, rabbits) that are visible to us, then that presentment of bonfire-byburning-live-trees is an existential shift.

Why had I become grumpy old man? What went wrong with all my organizing, and a score of YouTubes, and conference presentations? Teens and some misguided adults have been holding binge drinking parties, most weekends, burning tires, pallets, shooting beer bottles with pistols and rifles, and littering the place. For the past year, I collected broken and whole bottles, shoveled the burn and ash pits into my pickup, only to re-shovel the nasty mess into the dumpster on our farm. I took pictures of the vehicles, and the trash, and turned the reports into the 'No Throw' app on my cellphone. A student in one of my Ph.D. courses had developed the app. But nothing happened. It was COVID-19 epidemic of 2020, and Dona Ana County municipality was not doing anymore illegal dumping removal. On Dec. 15 2020, I watched as a young man unloaded more kindling and logs for the next bonfire at the pond.

I did my usual shamanic drumming, sitting on the pallets by the latest preparations for the bonfire. I noticed brand new tie down, yellow in color, with tag still on it. I pulled it from the soon to be burning pile of lumber, logs, and pallets. I drummed for my son Ray, and for clarity on what to do on the East Mesa. I faced Grandfather Hackberry Tree.

As I put my drum in its backpack, and get my two dogs, Sparkles and Cuddlebear, I heard the roar of the pickup with the American Flag on it. I walked right under the tree, and to the top of the berm on the other side. I had peace in my heart, and walked down into the pond to give the teen back his yellow tie-down rope. I did not judge, blame, or accuse. Just stayed in social distance, my mask in place, no mask on his face. We wished each other well.
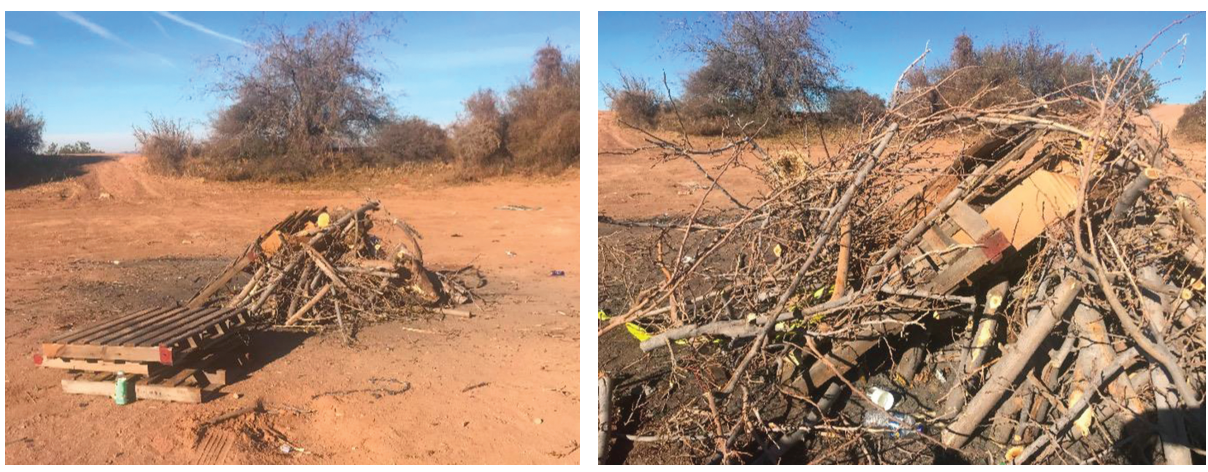

Figure 16.3: Bird's nest in the trees being added to burn pile about to be lit, still ready to burn, Dec 16 2020, with Grandfather Hackberry Tree visible in the distance, on the pond brim. 
As I looked at the bird's nest on December $15^{\text {th }}$, I was overwhelmed by the beauty of the scene, the little bird's nest, visible just beneath Grandfather Hackberry Tree, as he tends his new seedlings, waiting for better days.

With COVID-19, everything changed. The teens' drunken binging, and a fair number of adults, were generating more daily trash than I ever saw. It got to be more trash than I could manage to haul out, and overfilled our dumpster each week, so I hauled the excess to the landfill. I had become their enabler, picking up dirty diapers, COVID-masks, broken bottles. I had a change of heart. I am deciding this month, how to reach out to neighborhood teens, during this COVID-19 pandemic. I meditated daily, wrote in my notebooks, about water, and how it was inseparable from earth (the living soil under our feet), from fire (changes in heating of the planet), and from the air (getting more polluted). This insight of the inseparability of water, earth, fire, and air, had prompted me to abandon a 120,000 word book draft, and just start over. I was starting over a lot of drafts in 2020.

I meditated on how to have a heart of care for the ecosystem, and picked up trash and illegal dumping daily, to do the caring. I confronted teens and adults who carried guns, and picked up the trash in the midst of their drunken parties. I took pictures, and when I could get one of a license plate, I filled reports with county codes officers (via the 'No Throw' app) and made written reports with photos to Sheriff's Office. Nothing changed at all. I held a meeting, wearing COVID-19 masks with the manager of State Land Office (SLO), and a dozen neighbors, to discuss options for leasing the public land.

I was organizing neighbors, and talked to everyone in the Academy of Management. I let people know the laws of the matter. I looked into other regulations and ordinance. Again, all being violated with no enforcement whatsoever. I tried an appeal using social media. I began doing almost weekly videos (with Julia Haden and Duncan Pelly posted to YouTube) and making conference presentations. Many were about the onto-story the 'vibrant matter' of an assemblage of things. An onto-story is how the energy of an assemblage of things has a story to tell. Onto-story comes from the awesome work of Jane Bennett (2008 Vibrant Matter book). William James the pragmatist, says things tell a story. Here I find tires in the desert that are not yet burned, on a pile of already burned tires, beer cans and bottles, plastic of all types of bottled water, and other litter. It's a tragedy of the commons, the critical essence of living Earth, that nobody seems to care about, until the ground water is polluted by nano particles of plastic from what is being burned. Sure it's illegal, but what kind of education and parenting system raises its youth to not care. I pack out the tires, glass bottles, plastic battles, and so on.

In some videos, I make cob mix of horse manure (aka horse shit) to upcycle and make art of making walls and an Earthship? Greenhouse (See Appendix for videos). Again, this all had no positive result for the ecology and was not slowing down the teen-binge drinking (and quite a few adults). I was generating lots of videos, maps, pictures, and words, but not much has really changed. Rattling the governmental 
and enforcement cage, I managed to get one call back from a county worker, who looked up the history of the pond, and who had possible jurisdiction.

The ephemeral wetlands pond, might be over a century old, and redone in the public works program of the depression. It was possibly a stage coach stop, where the horses were watered, and before that a watering hole for the mining wagon horses to replenish their thirst. It had been a cattle grazing parcel, but not for some years. "Who owns this land?" I asked. "It's owned by the State Land Office”. State Land Office (SLO) is one of two divisions of the Federal Department of the Interior, the other one is Bureau of Land Management (BLM). Everyone even the elected city and county officials think its all BLM, but where I live its mostly SLO.

I checked the SLO rules and regulations: There are no motorized vehicles (no ATVs, no Motorcylcles, no OHMs, and no UTVs, pickup trucks, or cars) allowed beyond the parking lot. The 'Friends of EMT' pay \$35 a yeart to the New Mexico State Land Office for a recreational use permit. Target shooting is not allowed. Friends of EMT pack out everything they pack in. Here are 10 reasons why OHM, UTV, ATVs are destroying public lands, particularly on East Mesa.

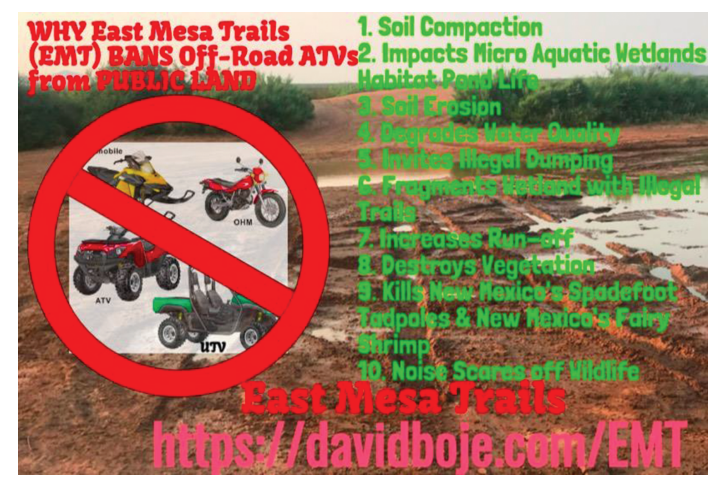

Figure 16.4: Ten ways recreational vehicles destroy the soil.

I looked with my horizontal third eye. I am vigilant, knowing a soon to be burned pile, left by teens and a few adults, a drunken beer and whisky fest soon to be consummated. With my vertical third eye, I am Arihant, and 'Surrenders To Spirt' aware of the spirituality of the Whole of Life, where I Indwell. Grandfather Hackberry Tree will continue to care for his seedlings, inviting Sumac Tree and the fungal strands to send water, carbon, sulphur, phosphorous, and nutrients to the seedlings. I reflect on my teen years. How exciting to have a chance to create community with the teens today. I wonder if nature and commerce can find a balance. Is it possible for business modeling to take an ecological turn (Bøje \& Jørgensen, 2020; Bøje \& Rana, 2021; Sparre \& Bøje, 2020). 


\section{Epilogue}

In May 2021, I discovered a grove of Hackberry tress, a dozen, all in a circle. It is a place that gives me hope.t

\section{References}

Bennett, M. F. (2008). Religious and spiritual diversity in the workplace. In M. A. Moodian (Ed.), Contemporary Leadership and Intercultural Competence: Exploring the Cross-Cultural Dynamics Within Organizations (pp. 45-60). SAGE PUBN.

Bøje, D. M. (2005). Wilda. Journal of Management, Spirituality \& Religion, 2(3), 342-364.

Bøje, D. M. (2012). The -of-care of the life-path of organizations' double-spiral-antenarrative choices through landscapes. https://davidboje.com/Boje/index.htm

Bøje, D. M., \& Henderson, T. L. (2014). Being Quantum: Ontological Storytelling in the Age of Antenarrative. Cambridge Scholars Publishing.

Bøje, D. M., \& Jørgensen, K. M. (2020). A 'storytelling science' approach making the eco-business modeling turn. Journal of Business Modeling, 8(4), 8-25.

Bøje, D. M., \& Rana, M. B. (2021). Defining a sustainably-driven business modeling strategy with a 'storytelling science' approach. In Handbook of Sustainability-Driven Business Strategies in Practice. Edward Elgar Publishing.

Chitrabhanu, G. S. (1978). Realized What You Are: The Dynamics of Jain Meditation. Dodd, Mead, and Company.

Chitrabhanu, G. S. (1979a). The Philosophy of Soul and Matter. Dhanjibhai P. Shah.

Chitrabhanu, G. S. (1979b). The Psychology of Enlightenment: Meditations on the Seven Energy Centers. Dodd, Mead, and Company.

Chitrabhanu, G. S. (1980). Twelve Facets of Reality: The Jain Path to Freedom. Dodd, Mead, and Company.

Gagliano, M. (2018). Thus Spoke the Plant: A Remarkable Journey of Groundbreaking Scientific Discoveries and Personal Encounters With Plants. North Atlantic Books.

Heidegger, M. (1926). Being and Time (J. Stambaugh, Trans.) State University of New York Press.

Heidegger, M. (1962). Being and Time (J. Macquarrie \& E. Robinson, Trans.) Blackwell. heidegger macquarrie robinson 1962 Being and time.

Henderson, T. L., \& Bøje, D. M. (2016). Managing Fractal Organizing Processes. Routledge.

Larsen, J., Bøje, D. M., \& Bruun, L. (2020). True Storytelling: Seven Principles for an Ethical and Sustainable Change-Management Strategy. Routledge.

Sparre, M., \& Bøje, D. M. (2020). Utilizing participative action research with storytelling interventions to create sustainability in Danish farming. Leadership \& Organization Development Journal, 38(4), 41-54. 


\section{Appendix}

Here are some of the videos we did on the East Mesa Ephemeral Pond Situation:

1. Take Care of Water and Water Takes Care of Us All Boje's Presentation to the Global Water Conference May 262020 https://youtu.be/X79a0q2cgn0

2. Videos is about Onto-Story https://youtu.be/6jhhJlky3zI An Onto-Story is the story that material Things like Spadefoot and Fairy Shrimp are telling to us. Ont-Story comes from the work of Jane Bennett (2008) and is a way to understand the vibrant mater of Things, and their relation to other things, such as the burned and about to be burned tires I am rescuing from the desert so that pollution does not further destroy Life On Desert Pond (pun intended).

3. PART I: Onto-Story of East Mesa Pond being Trashed at https://youtu.be/ 6jhhJlky3zI

4. PART II: Pack Out what Others Don't Pack Out to save Pond habitat. Video link https://youtu.be/S3XQUhAh6Ys

5. PART III: How to make Horse Manure Cob walls and Earthship Greenhouse to upcycle bottles and cans and plastic of Ephemeral Pond https://www.youtube. com/watch? $\mathrm{v}=\mathrm{xZ6VbM} 4 \mathrm{~N}-\mathrm{Wo}$

6. PART IV: What would Henry Thoreau Say about Trashing Ephemeral Pond? Video link https://youtu.be/L518-LQ2Lcs

7. PART V: What onto-story the burned trash of party goers has to tell humanity? Video link https://youtu.be/GwSVtXtk3XU

8. PART VI: What onto-story has trash bags littering Ephemeral Pond to tell us all? Video link https://youtu.be/_bchK1F_4R0

9. PART VII: As My Dad Always Said, Don't Just tell the problem, what Solution to you have? Video link https://youtu.be/IrgFh_ZIzrM

10. PART VIII: The Angel of Truth looking back on the wreckage upon wreckage of western civilization, piling up. Video Link at https://youtu.be/cFlsZO5Hvtw PART IX: What is the VERITAS of a place? Video link https://youtu.be/ knFURkkVo20

11. PART X: Why burning tires in Wetland Pond of East Mesa is ECOCIDE and your own SUICIDE? Video link https://youtu.be/vGAxl2AwVIs

12. PART XI: David Boje does Shamanic Drumming with Intention of Calling on Grandfather Tree of the Ephemeral Pond to enter SACRED SPACE and give thanks for this wetland place. Video link https://youtu.be/KhcCj2zTfaM

13. PART XII: How to dump your burn pit ashes in county landfill instead of in the East Mesa Wetlands Pond Video link https://youtu.be/sEgL_e4neao

14. PART XIII: Raving PartiersTrashing East Mesa Ephemeral in Las Cruces New Mexico Pond Sunday Jun 142020 at nooner-drunk-fest. Do they realize they are Polluting Jornada East Mesa Aquifer that feeds Mesilla Aquifer of Las Cruces Drinking Water for Everyone-, including themselves and the uniquely adapted aquatic creatures. Heck just inhaling the wood smoke with the nano-plastic 
particles is enough to mess up their lungs for life. Video link https://youtu.be/ L4dQIcLgBaA

15. Part XIV No Law on East Mesa of Las Cruces/County/BLM since COVID-19 and long Before David Boje, Video link https://youtu.be/tKwa48TZyfw

16. The D.r D and Princess Gaia interview with Boje about the importance of the Aliveness of Place https://youtu.be/zvPqyo5Gky8

17. Duncan and Julia is interview pond June $222020 \mathrm{https}$ ://youtu.be/uBU9ELxCW88.

18. ANTESTORY of Ephemeral Pond Fairy Shrimp and Spadefoot MICROCOSMOS David Boje Aug 2nd 2020 Video link https://youtu.be/JusLb78KPRg

19. Stardust Divination for Gathering of Circles - Shamanic journeying to Microcosmos Aug 1st 2020 Video link https://youtu.be/TpwWcYq439U

20. Why are there Carnivore and Omnivore New Mexico Spadefoot Toad Tadpoles 7 292020 Boje Video link https://youtu.be/ALL4z8ANyWE

21. Come out to see first spadefoot tadpoles of season EAST MESA EPHEMERAL POND July 272020 David Boje Video link https://youtu.be/oq1v_Hiihg0

22. Overstory and Understory of Walking with Wetlands Water to the Ephemeral Pond - David Boje interview July 242020 Video link https://youtu.be/ 7nXfzWtqIdU

23. Who says Temporary Water Does Not Exist? First Monsoon Rainstorm Fills East Mesa Wetlands Pond July 212020 Video link https://youtu.be/ECXlmwEy_3Q

24. Overstory and Understory of Walking with the Wetlands Waters to Ephemeral Pond Matters - David Boje July 142020 Video link https://youtu.be/Ggpy4lyLbI

25. Storytime with David - We are all made of Stardust 200803 Storytime with David - We are all made of Stardust 200803 - YouTube link is https://youtu. be/toouEbkobf8

26. Storytime with David - A Call for Visionaries 140720 https://youtu.be/ r55c031vqQg?list=PLijSv3zeLzZ_ovs9d7n3HPK8JGW-z8kyy

27. Aliveness of Place https://youtu.be/zvPqyo5Gky8 
